\title{
STUDY OF SAMPRAPTI BHED IN RAJYAKSHMA WITH SPECIAL REFERECE TO CHATURVIDH YAKSHMA HETU
}

\author{
Dr. Komal Patil , Dr. Madhavi Gaikwad \& Dr. Deepali Amale
}

\begin{abstract}
1.PG Scholar, Rog Nidan evum Vikruti Vidnyan Deptt 1CSMSS Ayurved College, Aurangabad 2. Associate Professor, Rognidan Evum Vikruti Vidnyan Deptt. , CSMSS Ayurved College, Aurangabad 3. Prof \& Hod, Rog Nidan Evum Vikruti Vidnyan Deptt. , CSMSS Ayurved College, Aurangabad
\end{abstract}

\begin{abstract}
Ayurveda - "science of life" is considered as the traditional system of medicine of India. The aim of this system is to prevent illness, heal the sick and preserve life. For the fulfillment of second aim of Ayurveda, it is necessary to diagnose the disease. It is not possible to cure a disease without proper diagnose. That is why Ayurveda has been described "Trisutra Ayurveda i.e. Hetu, Linga and Aushadha". Rajayakshma is a Madhyama Rogamarga Vyadhimanifested Shosha. Due to indulging in Sahasa, Vega Sandarana, Kshaya, Vishamashana, there is the manifestation of Ekadasha Rupa where it affects the Tridosha and Sapta Dhatu. Ayurveda classics gives importance to Nidana because it is a Sarva Tantra Siddanta that effect will always be going to imitate the cause i.e. Karya Karana Bhava. Before understanding Chikitsa the knowledge of Nidana and the Samprati is very necessary. Chikitsa is nothing but the Nidana Parivarjana and Samprapti Vighatana. Rajayakshma is an unique disease the classification of disease has been done on the basis of Nidana and Samprapti. According to the involved Nidana as Rajayakshma devided as Sahasajanya

Rajayakshma, Vega Sandarana janya Rajayakshma, Kshaya janya Rajayakshma, and Vishamashana janya Rajayakshma. As per the process of disease Rajayakshma is classified as anuloma Kshaya and Pratiloma Kshaya.
\end{abstract}

Key words: Rajayakshma, Samprapti, Nidana, Sahasa, Sandharana, Khaya, Vishamashana. 


\section{Introduction}

According to Ayurveda, health is defined as the state where physical body, senses, and psyche are in original or natural state with respect to body and function (1). The imbalance state of all those are known as Dhatu Vaishamy. There are so many diseases (Vyadhi) have been described in Ayurveda. Rajayakshma is also one of them. Rajayakshma is considered as king of all diseases (2). Rajayakshma is group of diseases gets manifested with the vitiation of Tridosha and Sapta Dhatu. Due to indulging in Sahasa, Vega Sandarana, Kshaya, Vishamashana, there is the manifestation of Ekadasha Rupa. (3) In modern era Shosha is considering as tuberculosis. It is a major public health problem. In India due to the Environmental Changes, Changes in Behavioural Dietic Habits, Poor Quality Of Life, Population Explosion, Under Nutrition, and Lack of Awareness about cause of disease and Modern Life Style. The causes and path of disease are changed in their pattern. The definition of Chikitsa explained by Acharya Charaka is perfectly applicable in case of Rajayakshma. He says that the treatment of disorders

Should consist of such as Treatment is given with the objective of ensuring that no discordance will arise in the Dhatus and there is continuance of their concordance (4).

\section{Aim and Objectives: Aim}

Study of Samprapti Bhed in Rajyakshma with special referece to Chaturvidh Yakshma Hetu

\section{Objectives}

1. To explore Yakshma Hetu and Samprapti in detail.
2. To enlighten the basic concept of Nidana and Samprapti of Rajayakshma to its full perspective.

\section{Material ad methods}

1. References of Rajayakshma from various Samhita like Charaka, Sushruta, Vagbhatta etc.

2. Compilation of information about Rajayakshma from Samhita, relevant books, journals, and modern science has been made.

\section{Rajayakshma Bheda}

(A) On the basis of etiological factors Chakrapani opines that according to the etiological factors

Rajayakshma can be classified into 4 types 1. Sahasaja Rajayakshma

2. Sandharanaja Rajayakshma 3. Kshayaja Rajayakshma

4. Vishmashanaja Rajayakshma

\section{Nidan (5)}

वेगरोधात् क्षयाच्चैव साहसाद्विषमाशनात् |

द्विदोषो जायते यक्ष्मा गदो हेतुचतुष्टयात् |। मा. द्वन. १०/१

After going through all the classics, it is found that there are four major causes of Rajayakshma that can cause the disease singly or combinedly. These are Sahasa, Vega Sandharana, Kshaya and Vishamashana.

\section{1) Sahasa -}

It means excessive and strenuous work or fight or exercise beyond ones capacity. Weak person fight with strong person, Hardworking with exertion, Excessive talkative/speaks too much Swims in water for long distance, Forceful massage, Application of pressure by feet, Runs fast to cover a long distance, indulging such other regimens, excessive physical exercise, studying for long duration, Fasting, Carries heavy weight, 
Injury, Heavy vehicle raiding following down from, height any other type of injury (6). Due to these in excesses vitiates Vata that affects the Kapha normally residing in Urha Pradesha vitiates Pitta moves upwards side wards and downwards.

\section{2) Vega Sandharana -}

This means suppression of natural urges for defecation, micturition etc. the person who are in front of king attending meeting with wise peoples, while travelling high or low vehicle, in front of female. Than Vata gets aggravated, this aggravated Vata will vitiates Pitta and Kapha (7).

\section{3) Kshaya -}

Kshaya means depletion. Acharya Sushruta has described it as the synonym of Shosha and explains that the loss of capability of body todo work is called Kshaya ${ }^{(8)}$. Gangadhara comments that in Rajayakshma it refers to depletion of Rasa Dhatu and Shukra while Yogendranath says that it refers to depletion of Shukra, Oja and Sneha. This may be because Rasa and Oja are taken as synonyms. According to both Acharya Charaka and Acharya Sushruta this depletion of Dhatus can take place by two ways that can be termed as (i) Anuloma Kshaya and (ii) Pratiloma Kshaya. Anuloma Kshaya means the depletion of Dhatus takes place in the direction of their nourishment i.e. Rasa then Rakta then Mamsa and so on. Pratiloma Kshaya means the depletion of Dhatus takes place in the direction opposite to their nourishment i.e. Shukra then Majja then Asthi and so on (9). According to Acharya Charaka, can be divided into 2 categories i.e.

Psychological like Bhaya, Shoka, Chinta, Udvega etc. and next is nutritional like intake of Ruksha Anna Pana by intake of less quantity of food, fasting by weak body, Ativyavaya Anahara. which when ingested lead to depletion of Dhatus by increasing Vata Dosha, inspite of giving nourishment to the body.

\section{4) Vishmashana}

Vishamashana was the main hetu of Rajayakshma in $29 \%$ volunteer. Akala bhojan, Alpa bhojan and Akala+Alpa bhojan were the reasons of Vishamashana in most of the volunteers. A person who has not followed rules of diet and took irregular diet, then it leads to the vitiation of vata dosha, which further aggravates the other two dosha. Imbalanced dosha obstruct the channels, by which Dhatu are not nourished properly and produce Rajayakshma due to irregular diet (vishamashana).

\section{Rajayakshma Samprapti (10)}

तैरुदीणोोंड द्वनलः द्वित्तों कर्फ चोदीयफ सवफतः।

शरीरसन्धीनाद्ववश्य तान् द्वसराश्च प्रीडयन्।।

मुखाद्वन स्रोतसा। रुद्वा तथैवाद्वतद्ववृत्य वा।

सिफन्त्वरफमधस्तियफग्यथास्वों जनयेडदरदान्।। .द्वन. $4 / 4, \xi$

अ.ह

In case of Rajayakshma Acharya Charaka has mentioned the pathogenesis of all the four types of Rajayakshma in details in Nidana Sthana. A common pathogenesis has been described in Chikitsa Sthana. Further, the pathogenesis of each of Ekadasharupa except Jwara has also been discussed by Acharya Charaka. Other Acharyas have mentioned pathogenesis of two types viz. Anuloma Kshaya and Pratiloma Kshaya.

\section{Vishishta Samprapti}

\section{Sahasaja Rajayakshma}

Excessive indulgence of various Sahasa Karma beyond ones capacity leads to injury in the chest including lungs. The Urastha Vata moves in the injured part of 
the chest and vitiates the local Kapha and Pitta. All these three Doshas together moves in the body upward, downward and obliquely and get localized in various body organs to produce symptoms accordingly. These symptoms have their own pathogenesis due to the Dosha vitiation on the specific sites viz. the Dosha situated in Sharira sandhi results in Jrimbha, Angamarda and Jwara. Jwara is caused by Vata provocation, Jrumbha occurs when the Dosha get lodged in Hanusandhi and when there is involvement of all Sandhis, Angamarda is observed. When Dosha is lodged in Amashaya, it results in Uroroga and Arochaka Uroroga here means the diseases of chest like Hridrava, Shoola etc. The Dosha situated in Amashaya causes diseases of chest because of the vicinity of chest to Amashaya. Yogendranath is of the view that Arochaka is caused because of Dosha situated in Rasana. Gangadhara opines that Arochaka is due to Dosha situated in Hridaya. When Dosha get situated in Kantha it causes Swarasada and when they get lodged in Pranavaha Srotas they results in Shwasa and Pratishyaya. When the Shirah gets occupied by provoked Dosha it causes Shirahshoola. Vata Dosha when get lodged in chest leads to Kanthodhwansa and Kasa. The continuous bouts of Kasa causes Shonitashthivana. Jyotishchandra suggests that it is because of the injury occurred in the Sira of Phuphusa. The Vata gets vitiated because of Rakta Kshaya leading to Daurbalya and manifest the disease. Varchobheda has been described as an additional symptom by Gangadhara and Yogindranath. Gangadhara mentions its occurrence because of Dosha situated in Guda. Yogendranathsen opines that to be because of Dosha vitiation in Amashaya. (11)

\section{Sandharanja Rajayakshma}

When any person suppresses the natural urges, it results in Vata provocation. This provoked Vata vitiates Pitta and Kapha. All these three move together through out the body upward, downward and obliquely. These then get settled in various sites. This all lead to manifestation of various symptoms as described earlier in Sahasaja Rajayakshma. Shoola and Purishabheda occur when Vata is vitiated by Ruksha and Chala Guna along with Pitta. Purishabheda leads to Atisara. both the latter symptoms occur due to Dosha anchored in Adhobhaga. Vitiated Vata when goes to Parshwa region it causes Atiruja. Gangadhara says that Shirahshoola occurs when Kapha Dosha occupy Shirah. Kasa, Jwara, Swarabheda and Pratishyaya are the other symptoms occurring in the disease (12). All these lead to gradual cachexia of the patient and ultimately Rajayakshma.

\section{Kshayaja Rajayakshma}

The manifestation of Rajayakshma by Kshaya takes place by two different pathways according to the direction in which depletion of Dhatus takes place. When a Durabala Prakriti person i.e. who is weak since birth indulges in the etiologic factors, it leads to depletion of Rasa residing in Hridaya. According to Gangadhara, Hridaya here refers to Manasa Sthana. The Rasa is the Sara of Annarasa and is Taijasa in nature. It is Dhatu Swaroopa and provides nourishment to other Dhatus. According to Chakrapani and some other Acharya refers Rasa to be Ojas (13). Due to its unavailability next Dhatu get depleted. This leads to cachexia as a result of depletion of all Dhatus. If this condition is not treated it ultimately results into Rajayakshma.

\section{Vishamashanaja Rajayakshma}


Vishamashana Sevana leads to imbalance of all the three Doshas i.e. Vata, Pitta and Kapha. These imbalanced Doshas moves in the body and get lodged into the orifices of various Srotamsi. This results in formation of faeces and urine by what so ever is ingested and no other Dhatu is formed. The patient lives only on Upasthambhana of Purisha. The vitiated Doshas combines with malnourished Dhatus and results in various symptoms leading to severe cachexia in the patient.

\section{Conclusion}

Rajayaksma is a Tridoshaja Vyadhi with the dominance of Vata and Kapha Dosha and it is an ideal example for Madhyama Roga Marga. Here all the Sapta Dhatus are involved in the manifestation of Rajayaksma, where all Dhatu are in Kshayavasta. The symptoms of Rajayakshma is differs according to the involvement of Sahasa (by excessive stress and strain) Vegasandarana (suppressing the natural urges), Kshaya (diminishing if Dhatu) Vishamashana (opposite to dietary regimen). The manifestation of Rajayakshma by Kshaya takes place by two different pathways according to the direction in which depletion of Dhatus takes place. Before planning the treatment it is very necessary to understand the involvement of causes in the diseases and process of pathogenesis.

\section{References}

1). Sushruta, Sushruta Sutra 15/48, In Sharma PV. Sushruta Samhita (with English translation of text and Dalhan's commentary along with critical notes) Vol I, Reprint edition, Varanasi, Chaukhambha Visvabharti 2005.

2). Vagbhata, Ashtanga Hridaya Nidana 5/3, In K R Shrikantha Murthy, Ashtanga
Sangraha of (text book withenglish translation) Vol I, Third edition, Varanasi.

3). Yadavaji Trikamaji, editor. Charaka Samhita of Charaka, Nidana Sthana, chapter 8, verse no.4. reprinted, Varanasi; Chowkhambha Sanskrit Series; 2008,193

4) pandita Ramswarupa sharma, editor atharvaveda samhita, Ath 7/76/5, chaukamba orientalia, varanasai vol-3 $3^{\text {rd }}$, $7^{\text {th }}$ edition 2001,193 5) Madhav Nidana (uttarardha) tika 10/1, Edited by Ayurved Acharya Shriyaduna ndanopadhya, publication chaukhamba Sanskrit Sanstha, 25 th edition- 1995

6) Yogaratnakara Yadavaji Trikamaji, editor. Charaka Samhita of Charaka, Nidana Sthana, chapter 6, verse no.5. reprinted, Varanasi; Chowkhambha Sanskrit Series; 2008

7). Yadavaji Trikamaji, editor. Charaka Samhita of Charaka, Nidana Sthana, chapter 6, verse no.6. reprinted, Varanasi; Chowkhambha Sanskrit Series; 2008,218

8). Vaidya Jadavaji Trikamji Acharya, editor. Sushruta Samhita of Sushruta with Nibandha Sangraha Comm. Of Shri Dalhanacharya, Nidana Sthana, chapter 41, verse no 9, Chaukhambha Orientalia, Varanasi, reprited, edition 2008,712

9) Vaidya Jadavaji Trikamji Acharya, editor. Sushruta Samhita of Sushruta with Nibandha Sangraha Comm. Of Shri Dalhanacharya, Nidana Sthana, chapter 41, verse no 9, Chaukhambha Orientalia, Varanasi, reprited, edition 2008,712

10) Vagbhata, Ashtangahridyama, With Nirmala Commentary Edited by Dr.Bramhananad Tripathi, (A.H.NI.5/5,6)
Reprinted 
2012, Chaukhamba Sanskrit Pratishtana, Delhi.

11) Yadavaji Trikamaji, editor. Charaka Samhita of Charaka, Nidana Sthana, chapter 6, verse no.4. reprinted, Varanasi; Chowkhambha Sanskrit Series; 2008, 217

12) Yadavaji Trikamaji, editor. Charaka Samhita of Charaka, Nidana Sthana, chapter 6, verse no.6. reprinted, Varanasi; Chowkhambha Sanskrit Series; 2008, 218

13) Yadavaji Trikamaji, editor. Charaka Samhita of Charaka, Nidana Sthana, chapter 6, verse no.6. reprinted, Varanasi; Chowkhambha Sanskrit Series; 2008, 218 


\section{Pathogenesis of Pulmonary Tuberculosis ${ }^{1,2}$}

\section{ARTHUR M. DANNENBERG, JR.}

\section{Introduction
Tuberculosis remains the classic ex-} ample of a disease that is controlled almost entirely by cell-mediated immunity, involving the macrophage as the effector cell and the lymphocyte (especially the T-cell) as the immunoresponsive cell. This type of immunity is also called acquired cellular resistance; it and the antibody-type of immunity (involving B-lymphocytes) are the two basic immune mechanisms of the host.

Cell-mediated immunity is essentially a local phenomenon carried out by macrophages that are activated locally at the site of infection by lymphocytes and their lymphokines. It is intimately linked with cellular (or delayed) hypersensitivity.

Tuberculous granulomas are similar to the granulomas of berylliosis, sarcoidosis, and the systemic mycoses. The pneumoconioses and other fibrotic lung diseases (e.g., those induced by ozone, cadmium, or bleomycin) may also involve the same basic mechanisms.

In this review, the pathogenesis of tuberculosis is used to illustrate macrophage function, cell-mediated immunity, cellular hypersensitivity, and granuloma formation - all of which have bearing on a variety of diseases that affect mankind.

\section{Genetic Factors}

Genetic factors play important roles in many diseases, and tuberculosis is no exception (1-4). Because tuberculosis in rabbits is more like human tuberculosis than tuberculosis in most other species, Lurie $(3,5)$ developed inbred rabbit families that were genetically resistant or susceptible to this disease. The resistant rabbits (exposed to virulent bovine-type tubercle bacilli) had cavity formation and bronchogenic spread, whereas the genetically susceptible rabbits had noncavitary caseous foci with hematogenous spread. The resistant families mobilized more macrophages at the site of infection and formed mature epithelioid cells more rapidly than the susceptible families.
Mature epithelioid cells usually inhibited the growth of the tubercle bacillus in their cytoplasm, whereas immature epithelioid cells (found frequently in susceptible rabbits) usually allowed the bacillus to multiply there. (Epithelioid cells are large macrophages with a vesicular, or euchromatic nucleus, often resembling epithelial cells in appearance [see 6].)

In general, the resistant rabbits formed antibodies and developed cellular hypersensitivity more rapidly than susceptible rabbits $(3,5)$. Breeding of the resistant with susceptible rabbits (and back-crossing the $F_{1}$ hybrid) showed that the genetic factors controlling resistance to tuberculosis are multiple, additive, and dominant over those that control susceptibility (3). Studies with other animal species are consistent with this conclusion. They were reviewed by Lurie (3).

The role of genetic factors in the pathogenesis of tuberculosis in man is less clear than it is in animals. Genetic constitution is an important risk factor for the development of clinical tuberculosis (7). For instance, blacks with the HLA antigen Bw15 showed a higher incidence of tuberculosis and more advanced disease than blacks with other genotypes (8). Whether blacks on the whole are more susceptible to tuberculosis than whites has not been conclusively determined $(2,3,9)$.

Some patients with recently diagnosed tuberculosis could be characterized as low responders to tuberculin (10). Low responsiveness was correlated with the presence of circulating suppressor adherent cells, probably monocytes. These findings seemed to have a genetic basis, although the genotypes of these patients were not studied.

The role of genetic factors in the immune response and in various infectious diseases was recently reviewed $(11,12)$. Additional references concerning HLA antigens and tuberculosis appear in (8) and (10).

A comparison of tuberculosis in dif- ferent mammalian species gives further insight into the nature of native resistance to this disease (13-15). Such resistance is not related to degrees of tuberculin hypersensitivity. Rats and hamsters develop low degrees of sensitivity and show little or no caseation. Yet, rats are quite resistant and hamsters quite susceptible. Modern man and guinea pigs develop substantial degrees of hypersensitivity and show considerable caseation. Yet, man is rather resistant and the guinea pig quite susceptible.

In the final analysis, what determines whether the disease progresses or regresses is the power of the macrophage to inhibit the growth of tubercle bacilli within its cyroplasm (3). The macrophage cytoplasm of some mammalian species is probably not a favorable milieu for bacillary growth, especially after acquired resistance is superimposed on the native resistance (3).

Why tubercle bacilli survive within the macrophages of susceptible species is unknown. One of undoubtedly many reasons is that these bacilli can prevent the fusion of primary lysosomes with the phagocytic vacuole in which they live (16). Primary lysosomes contain microbicidins and hydrolytic enzymes that help kill the bacillus and break down its components.

Finally, differences exist in the susceptibility of various organs to tuberculosis, although the growth of bacilli in each organ is controlled by presumably identical macrophages arriving at the site from the bloodstream (3). In

- From the Departments of Environmental Health Sciences and Epidemiology. School of Hygiene and Public Health, and Department of Pathology, School of Medicine. The Johns Hopkins University, Baltimore, Maryland 21205.

2 Supported by Grant No. HL-14153 from the National Heart, Lung, and Blood Institute for the Johns Hopkins Specialized Center on Lung. U.S. Public Health Service: and Grants No. ES-01879 and No. ES-00454 from the National Institute of Environmental Health Services, U.S. Public Health Service. 